【カテコリリーII】

特別養護老人ホーム・介護老人保健施設における火災時の避難安全性に関する研究

\title{
STUDY ON THE REFUGE AND SAFETY IN THE FIRE AT NURSING HOME AND HEALTH CARE FACILITIES
}

\author{
村 井 裕 樹*，志田弘二**，八藤後 猛***，野 村＼cjkstart歡**** \\ Hiroki MURAI, Kouji SHIDA, Takeshi YATOGO \\ and Kan NOMURA
}

\begin{abstract}
It investigated to nursing home and health care facilities which are in Japan. The contents are the following five items about the refuge safety of the resident in case of a fire. The problem about shortage of the number of the institution personnel of night, the protection from smoke of the room, and refuge instrument use became clear.

1. A resident's move capability and the relation of the number of the personnel.

2. The opening situation of the room, and a smoke-free relation.

3. The installation situation of a refuge instrument, and validity of use.

4. The enforcement item and participating situation of disaster prevention training.

5. The number of residents according to room condition.
\end{abstract}

\author{
Keywords: $\quad$ Fire safety, Safety refuge, The efforts movement difficulty person, Fire escape apparatus, \\ Disaster prevention training \\ 火災安全，避難安全，自力移動困難者，避難器具，防災訓練
}

\section{1. 研究目的}

高齢社会を迎えたわが国では，在宅福祉施策を基本としながら も，多くの高跉者保健福祉施設（以下「施設」と略す）が建設され， この傾向は今後もしばらく継続すると推測されている。これら施設 の居住性に関する研究はさまざまな角度から継続的に行われている が，避難安全性に関する研究は十分とはいえず，建築的な避難計画 はもとより, 消防法令で設置される避難器具を高齢者が有効に使用 できるかの疑問も指摘されている洋1)。本研究ではこの点に着目し， 特別盖護老人ホーム注2) と介護老人保健施設注 31 に入所する高齢者の 火災安全が担保される施設計画を, 建築計画と避難器具の両面から 検討することを目的とした。

\section{2. 調査概要}

1980 年〜 1998 年に開設された全国の特別養護老人ホーム（以下 〈特盖〉) 及び介護老人保健施設（以下く老健〉) を無作為に抽出し, 防火・避難に関する 25 項目のアンケートを依頼した（調査期間： 2000 年 11 月中旬 12 月中旬)。調査項目の概要を表 1 に, 調査票 の発送数・回収数等を表 2 に示す。なお，以下では，回答に不備の ある施設，複数の建物に入所者の居室のある施設 4 ( 1 等の分析精度 を下げる要素のある施設を除いた，有効回答数く特養〉261，〈老趾

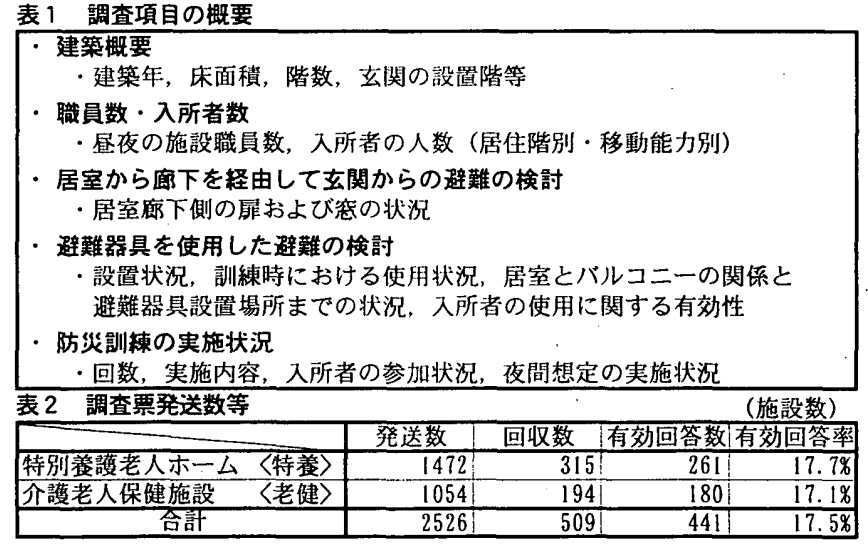

$>180$ の，計 441 施設を対象とする。

建物の建設年の分布を図 1 に示す。〈老健〉は1986 年からの制度 であるが，とくに近年のものが多くを占めている壮ら。建物の玄関 階と玄関階から最も離れた階との階数の差 (以下，「建物階数差」)迬6) を表 3 に示す。〈特養〉は建物階数差 0 が $41.4 \%$ で最も多く, 建物 階数差 $1 \sim 3$ で $52.5 \%, 0 \sim 3$ で $93.9 \%$ を占める。〈老健〉は建 物階数差 2 が最も多く, 建物階数差 0 は $16.1 \%$ でく特盖〉に比較し て少ない。建物階数差 $1 \sim 3$ で $68.9 \%, 0 \sim 3$ で $85.0 \%$ を占め, 建物階数差 $0 ， 1 ， 3$ の割合はほぼ同じである。

\footnotetext{
* 日本大学理工学部建築学科 大学院生 $\cdot$ 工修

** 名古屋市立大学芸術工学部 助教授・工博

*** 日本大学理工学部建築学科 助手. 工修

**** 日本大学理工学部建築学科 教授・工博
}

Graduate Student, Dept. of Architecture, College of Science \& Technology, Nihon Univ., M. Eng.

Assoc. Prof., School of Design and Architecture, Nagoya City Univ., Dr. Eng Research Assoc., Dept. of Architecture, College of Science \& Technology, Nihon Univ., M. Eng.

Prof., Dept. of Architecture, College of Science \& Technology, Nihon Univ., Dr. Eng. 


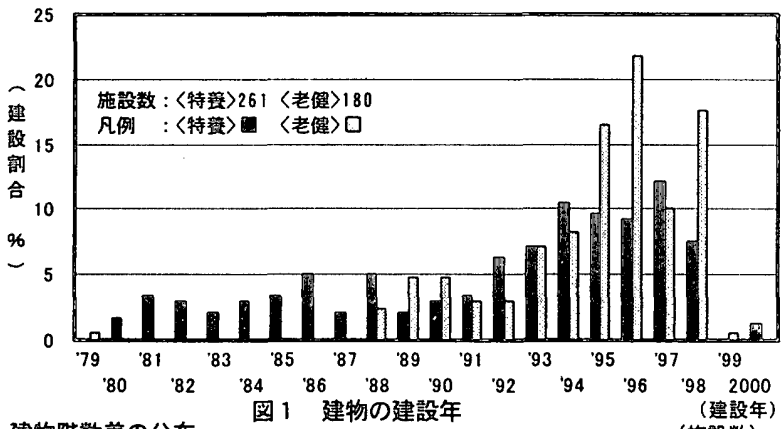

表 3 建物階数差の分布 图 1 建物の建設年

\begin{tabular}{|c|c|c|c|c|c|c|c|}
\hline 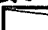 & Dent & \multicolumn{2}{|c|}{ 〈特㪨〉 } & \multicolumn{2}{|c|}{ 〈老健〉 } & \multicolumn{2}{|c|}{ 合話 } \\
\hline \multirow{11}{*}{$\begin{array}{l}\text { 建 } \\
\text { 物 } \\
\text { 茈 } \\
\text { 数 } \\
\text { 差 }\end{array}$} & 0 & 108 & 41.48 & 29 & 16.18 & 137 & $31.1 \%$ \\
\hline & 1 & 67 & $25.7 \%$ & 33 & $18.3 \%$ & 100 & $22.7 \%$ \\
\hline & 2 & 43 & $16.5 \%$ & 61 & $33.9 \%$ & 104 & $23.6 \%$ \\
\hline & 3 & 27 & 10.38 & 30 & $16.7 x$ & 57 & 12.9 \\
\hline & 4 & 6 & $2.3 \%$ & 16 & $8.9 \%$ & 22 & 5.0 \\
\hline & 5 & 2 & $0.8 \%$ & 7 & 3.98 & 5 & 2.0 \\
\hline & 6 & 3 & 1.18 & 3 & $1.7 \%$ & 6 & 1.4 \\
\hline & 7 & 2 & $0.8 \%$ & 0 & $0.0 \%$ & 2 & 0.5 \\
\hline & 8 & 2 & $0.8 \%$ & 1 & $0.6 \%$ & 3 & 0.7 \\
\hline & 9 & 1 & 0.48 & 0 & $0.0 \%$ & 1 & 0.2 \\
\hline & 拿訪 & 261 & $100.0 \%$ & 180 & 100.08 & 441 & $100.0 \%$ \\
\hline
\end{tabular}

\section{3. 調查結果と考察}

調査結果を，入所者の移動能力と施設職員数，居室から廊下を経 由して玄関からの避難, 居室からバルコニーを経由して避難器具を 使用した避難, 防災訓練の実施状況, 居室条件別の居住者人数の, 計 5 項目に分類してまとめた。考察は各項目ごとに述べている。

\section{1. 入所者の移動能力と施設職員数}

\subsection{1. 入所者の移動能力}

入所者の避難行動能力は, 入所者の移動能力と施設職員の介助力 の双方に大きく左右される。避難時の移動能力の調查は不可能なた め, 日常の移動能力を「全面的に介助が必要」から「自力で移動が可 能」まで 5 段階に分類して調査・分析した(表 4)。

〈特着〉は，「全面的に介助が必要」が53.7\%で，「部分的に介助が 必要」を含めると $71.9 \%$ が移動に何らかの介助を必要とする。く老 健〉は，これが56.7\%で，移動に介助を必要としない者の割合が 〈特盖〉に比べて多い。自力では移動できないと考えられる「全面的 に介助が必要」部分的に介助が必要」を「自力移動困難者」，それ以 外（介助を必要とせず自力で移動が可能）の場合を「自力移動者」 という名称で大分類して以下で分析する。「自力移動困難者」の割合 の分布を図 2 , 基本統計量を表 5 に示す。「自力移動困難者」の割合 は，〈特盖〉は $70 \%$ 台の施設が多く，50\%赤満は $8.8 \%$ と少ない。く

\begin{tabular}{|c|c|c|c|c|}
\hline \multirow[t]{2}{*}{ 表 } & \multicolumn{2}{|c|}{ 移動能力の分頻 } & \multicolumn{2}{|c|}{ (人数：\%) } \\
\hline & & \begin{tabular}{|l|}
$\langle$ 特盖〉| \\
$N=216$
\end{tabular} & $\begin{array}{l}\langle\text { 老健〉| } \\
N=145\end{array}$ & 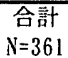 \\
\hline & $\begin{array}{l}\text { 全面的に介助 } \\
\text { が必要 }\end{array}$ & 53.7 & 34.6 & 44.4 \\
\hline 移 & $\begin{array}{l}\text { 部分的に介助 } \\
\text { が必要 }\end{array}$ & $18.2 !$ & 22.1 & 20.1 \\
\hline $\begin{array}{l}\text { 能 } \\
\text { 力 } \\
\text { の }\end{array}$ & $\begin{array}{l}\text { 自力で車いす } \\
\text { に乗移り、移 } \\
\text { 動可能 }\end{array}$ & $11.0^{\prime}$ & 16.0 & 13.4 \\
\hline 分 & $\begin{array}{l}\text { 杖等を使用し } \\
\text { て移動可能 }\end{array}$ & 7.8 & 13.9 & 10.8 \\
\hline & $\begin{array}{l}\text { 自力で移動可 } \\
\text { 能 }\end{array}$ & 9.3 & 13.5 & 11.4 \\
\hline & 合計 & 100.0 & 100.0 & 100.0 \\
\hline
\end{tabular}

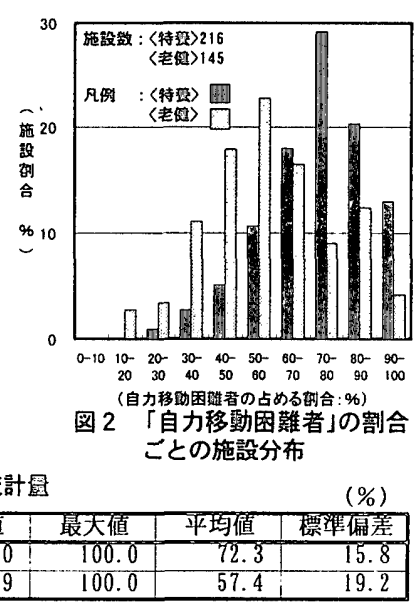

老健〉は $50 \%$ 台の施設が最も多く, 正規分布的に分布している。

\subsection{2. 自力移動困難者と施設職員数の関係}

入所者の避難を介助する施設職員数と入所者の移動能力の関係を 分析する。設定した時間帯は, 昼間は, 食事の介助等があるため, 臨時の施設職員增加の影響を受けにくい午後 2 時, 夜間は, 最も施 設職員の少なくなる哚夜の午前 2 時とした。なお，同じ施設内に滞 在している施設職員は, 非常放送を聞いて, 避難介助が必要な階へ 全員がかけつけるものと想定した。

施設職員一人が介助する必要のある「自力移動困難者」の人数(「自 力移動困難者」数を施設職員数で除した值)をみると, 表 6 および図 3 となる。表 6 より,〈特盖〉老健〉で平均值の差はほとんどな く, ともに夜間は昼間より平均值でかなり多くの人数を介助する必 要があることが分かる。図 3 より，昼間は，〈特盖〉老健〉ともに， $1 \sim 2$ 人にピークがあり分布形状は似ていて, 夜間は, 〈特峑〉は $12 \sim 13$ 人にピークが, 〈老健〉は $11 \sim 12$ 人にピークがあり, 分布 形状は似ているが，〈老健〉のほうがばらつきがある。

\subsection{3. 考察}

入所者の移動能力は, 〈特盖〉は, 「自力移動困難者」の割合がく老 健〉より多く,〈老健〉は入所者の移動能力がく特盖〉より平均化 されている。これはく特養〉のほうが身体能力の低下した入所者が 多く, 〈老健〉は一時入所という両施設の日常介護上の特徵と一致 する。入所者の移動能力の視点からは，〈特盖〉はく老健〉に比べ て火災時の避難に関して不利となることが分かった。

「自力移動困難者」と施設職員数の関係では, 夜間は施設職員一人 あたり数十人を介助する必要が示された。施設職員だけでは限界が あるので，これを補う建築・設備面での配虑が重要になる。

\section{表 6 瞕員一人あたりの「自力移動困難者了数の基本統計圆}

\begin{tabular}{|c|c|c|c|c|c|}
\hline & & 最小值 & 最大值 & 平㚬值 & 標準偪差 \\
\hline \multirow{2}{*}{$\begin{array}{l}\langle\text { 〈特荃〉 } \\
\mathrm{N}=209\end{array}$} & 蒝間 & 0.4 & 15.3 & 2.2 & 1.5 \\
\hline & 夜間 & 4.0 & $\overline{26.0}$ & 11.9 & 3.8 \\
\hline \multirow{2}{*}{$\begin{array}{l}\text { 〈老健〉 } \\
N=135\end{array}$} & 昼間 & 0.2 & 6.3 & 1.7 & 0.9 \\
\hline & 夜間 & 2.5 & 40.0 & 12.5 & 5.5 \\
\hline
\end{tabular}
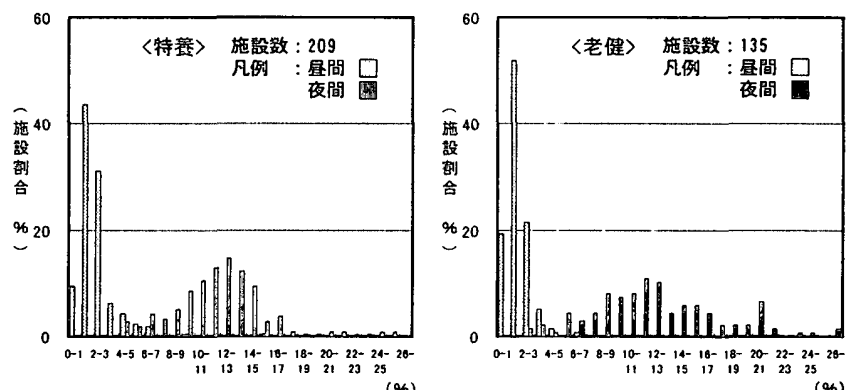

図 3 職員一人あたりの自力移動困難者」数による施钤分布

\section{2. 廊下を経由した避難の安全性}

\section{2.1. 居室の廊下に接する扉・空の状況}

居室廊下側の出入口に戸があり，廊下側の空がガラス等で閉じて いること(居室と廊下が区画されている) は，居室と廊下の間で煙の 移動を遮ることが可能で避難安全上有効な睘境である。居室廊下側 の出入口が開き戸や引き戸で仕切られているか (以下「悲あり」とい う) カーテン等のみの開放状態か (以下「覀なし」という), 居室廊下 側の空にガラス等煙を遮るものが使用されているか否か(使用され てない場合を以下「すき間あり」という）を調査した結果でクロス表 を作成した (表 7 ) ほ 7 。〈特盖〉は屝が「屝なし」の割合が〈老健〉よ りも高いこと, 両施設とも窓が「すき間あり」の状況は少ないことが 


\begin{tabular}{|c|c|c|c|c|c|c|c|}
\hline \multirow{4}{*}{\multicolumn{2}{|c|}{7}} & 毃(执 & & & & \multicolumn{2}{|c|}{ （施設数） } \\
\hline & & \multicolumn{4}{|c|}{ 廊下側罪の状況 } & \multirow{2}{*}{\multicolumn{2}{|c|}{ 合計 }} \\
\hline & & \multicolumn{2}{|c|}{ 罪あり } & \multicolumn{2}{|c|}{$\begin{array}{c}\text { 䨿なし } \\
\text { (カーテンのみ等) }\end{array}$} & & \\
\hline & & 〈特釷〉 & $\begin{array}{l}\langle\text { 老健〉 } \\
\end{array}$ & 〈特意〉 & 〈老健〉 & 〈特盖〉 & 〈老健〉 \\
\hline の廊 & 壁もしくは & 170 & 160 & 32 & 8 & 202 & 168 \\
\hline 状下 & カララス公等あり & $81.3 x$ & $94.7 \%$ & $15.3 \%$ & 4.78 & $96.7 \%$ & $99.4 \%$ \\
\hline 況 側 & & .7 & 0 & 0 & 1 & 7 & \\
\hline 空 & 9 さ間あり & $3.3 \%$ & $0.0 \%$ & $0.0 \%$ & $0.6 \%$ & $3.3 \%$ & $0.6 \%$ \\
\hline & 合計 & 177 & 160 & 32 & 9 & 209 & 169 \\
\hline & 口व। & $84.7 \%$ & $94.7 \%$ & $15.3 \%$ & $5.3 \%$ & $100.0 \%$ & $100.0 \%$ \\
\hline
\end{tabular}
わかった。防煙上有利な組み合わせである「扉あり」と「壁もしくは ガラス空等あり」は, 〈特養〉81. 3\%, 〈老健〉94.7\%となった。

\subsection{2. 玄関設置階と居室の最大階数差}

日常使用している玄関を設置する階を「玄関階」「玄関階と玄関階 から最も離れた居室のある階との差」を「階数差」と呼ぶことにする 注8)。表 8 より, 階数差 0 すなわち玄関階のみに居室のある場合は， 〈特盖〉が $47.1 \%$ でく老健〉の $18.9 \%$ よりかなり多く, 階数差 1 も 〈特養〉は $26.8 \%$ でく老健〉の $22.2 \%$ より多い。階数差 2 以下でく 特養〉は $92.7 \%$,〈老健〉は $84.4 \%$ である。階数差 4 以上は,〈特 養〉は施設数が減少し，〈老健〉はく特養〉に比べて多くなる。 表 8 階数差の分布 (上段: 施設数 中段: \% 下段: 界積\%)

\begin{tabular}{|c|c|c|c|c|c|c|c|c|}
\hline & \multicolumn{7}{|c|}{ 階数差 } & \multirow[b]{2}{*}{ 合計 } \\
\hline & 0 & 1 & 2 & 3 & 4 & 5 & 6 & \\
\hline \multirow{3}{*}{ 〈特養〉 } & 123 & 70 & 49 & 16 & 0 & & 2 & 26 \\
\hline & 47.18 & $26.8 \%$ & $18.8 \%$ & $6.1 \%$ & $0.0 \%$ & $0.4 \%$ & $0.8 \%$ & 100.0 \\
\hline & $47.1 \%$ & $73.9 \%$ & $92.7 \%$ & $98.9 \%$ & $98.9 \%$ & $99.2 \%$ & $100.0 \%$ & - \\
\hline \multirow{3}{*}{ 〈老健〉 } & 34 & 40 & 78 & 21 & 5 & 1 & & 18 \\
\hline & 18.98 & $22.2 \%$ & $43.3 \%$ & $11.7 \%$ & $2.8 \%$ & $0.6 \%$ & $0.6 \%$ & 100.0 \\
\hline & $18.9 \%$ & $41.1 \%$ & $84.4 \%$ & $96.1 \%$ & $98.9 \%$ & $99.4 \%$ & $100.0 \%$ & - \\
\hline \multirow{3}{*}{ 合計 } & 157 & 110 & 127 & 37 & 5 & 2 & 3 & 44 \\
\hline & $35.6 \%$ & $24.9 \%$ & $28.8 \%$ & $8.4 \%$ & $1.1 \%$ & $0.5 \%$ & $0.7 \%$ & 100.0 \\
\hline & $35.6 \%$ & $60.5 \%$ & $89.3 \%$ & $97.7 \%$ & $98.9 \%$ & $99.3 \%$ & $100.0 \%$ & - \\
\hline
\end{tabular}

\subsection{3. 考察}

〈特養〉では,「屝なし」の状態がく老健〉より多かった。これは， 〈特養〉の建設年がく老健〉より旧いものが多いことや，入所者の 身体能力が低いため，施設職員による日常介護の負担低減などが反 映された結果と思わ扚る。り「自力移動困難者」が多いく特養〉で は，火災時に居室と廊下の間の防煙性はより高いことが望ましいの で, 日常の介護と避難安全の要求の調整が重要である。

階数差は，〈特養〉がく老健〉より低い傾向にあるが，これは「自 力移動困難者」の割合が多いく特養〉においては避難安全上有利で ある。しかし, 定員が多い場合は建築形状は平面的に広がるため, 法的規制にこだわらない小さな防火区画などの検討が重要である。

\section{3. 避難器具を使用した避難}

居室からバルコニーを直接経由して避難器具を使用する避難方法 を検討する。消防法施行令第 25 条に規定される避難器具を対象过9 とした。すべり台は，回転式は高層階まで対応できるが, ‘直線式は 低首階までの対応であるため, 分けて分析した。本稿では避難器具 名を以下く >内のように略称する。回転式のすべり台（以下く回 転〉), 直線式のすべり台 (以下〈直線〉), 救助袋 (以下〈救助袋〉), 避難はしご(以下くはしご〉), 避難用タラップ(以下くタラップ〉), 緩降機(以下〈緩降機〉)，避難橋(以下〈避難橋〉)。〈回転〉〈直線 〈避難橋〉の例を写真 1 写真 3 に示す。調査項目は表 9 である。

\subsection{1. 避難器具の設置状況}

避難器具の設置状況を，建物階数差ごとに表 10 に示す。設置数 は, 避難器具の種類で異なり，〈特養〉老健〉ともにく回転〉が最 も多く, 次にく直線〉く救助袋〉が多い。これらで, 設置全避難器 具の, 〈特養 $>80.0 \%$ ，〈老健 $>82.9 \%$ と多くを占めているため，こ
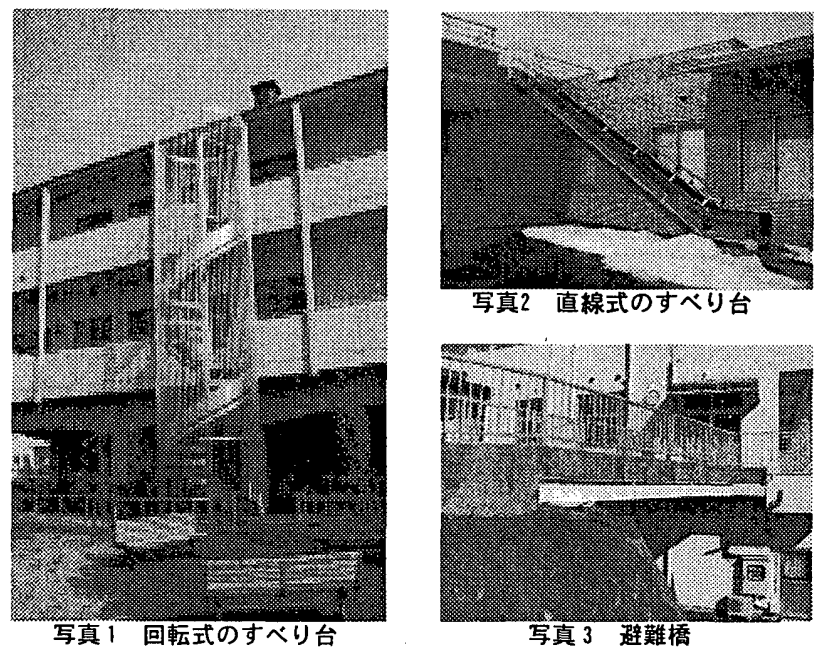

表 9 避難器具に関する調査項目概要

- 設圈されている避難器具の種類

施設䁚員の避難器具使用方法の理解と操作感

居室から避難器具設置場所に至るまでのバルコニーの状況

入所者が避難器具を使用することの有効性に関する施設職員の考え方

表10 避難器具の設置状況版：設置施設数 下段：\%)

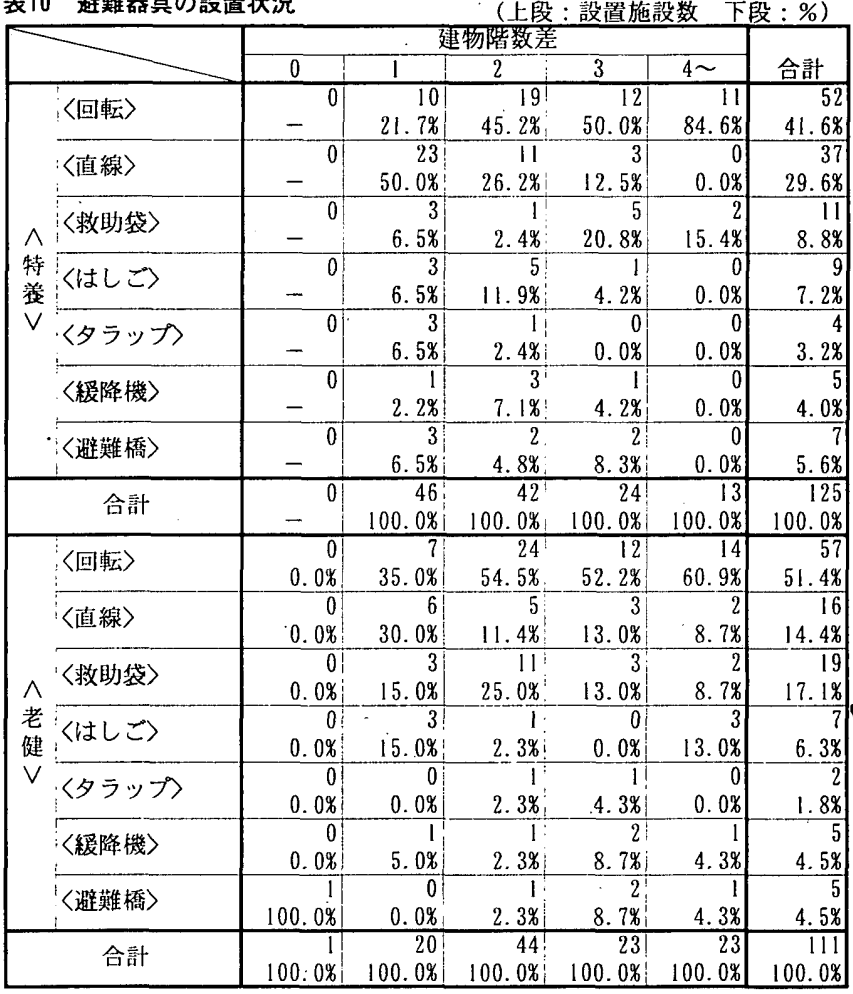

の三種を主に検討する。

- 建物階数差 1 〈特盖〉はく直線〉が $50.0 \%$ で最も多く，次いで 〈回転〉が多く，他はく緩降機〉を除いて設置施設数は同じである。 〈老健〉はく回転〉とく直線〉の設置施設数がほぼ同じである。

・建物階数差 2 〈特羌〉はく回転〉が $45.2 \%$ で最も多く,〈回転 〉とく直線〉以外は設置施設数がばらつく。く老健〉はく回転〉が $54.5 \%$ で最も多く, 次いでく救助袋〉く直線〉の順になる。これら 三種以外はほとんどない。

・建物階数差 3 〈特盖〉はく回転〉が $50.0 \%$ で最も多く, 次いで 〈救助袋〉〈直線〉の順になる。〈老健〉は，〈回転〉が $52.2 \%$ と最 も多く，その他は $13.0 \%$ 以下である。

・建物階数差 4 〜 〈特盖〉はく回転〉が $84.6 \%$ を占めるが, 〈老 
健〉は $60.9 \%$ あ゙あ。

\section{3. 2. 居室から避難器具までのバルコニーの経路状況}

居室からバルコニーを直接経由し避難器具に移動できる可能性を 検討する。居室からバルコニーへ直接出られる施設を対象として表 11 の内容を調查した。表 12 は, 表 11 の各項目の組み合わせによる 結果である。く特養〉は $62.0 \%$ でベッド以外の方法ならば避難器具 に到着可能で，歩行のみと車いすでほぼ同じ割合が到着できる。 ベッドで到着できるのはく特養〉9.8\%，〈老健〉10.0\%である。全 ての方法で到着できない場合は，〈特盖〉10.9\%，〈老健〉3. $3 \%$ で ある。全体の傾向は,〈老健〉も〈特盖〉とほぼ同じである。

表11 バルコニー通行状況の調查項目

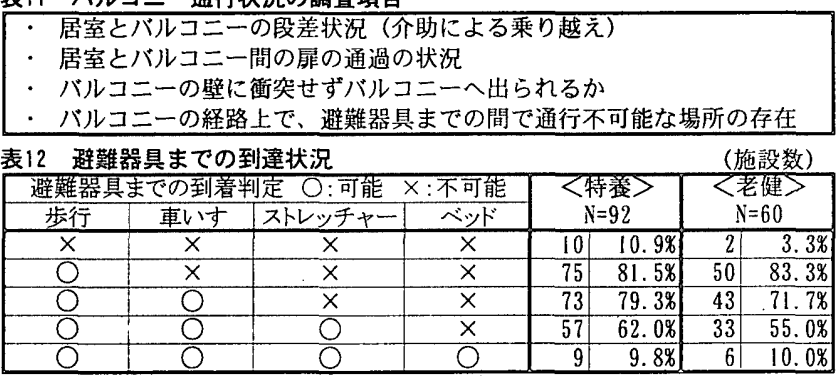

\subsection{3. 避難器具使用方法の理解}

施設職員が消防署職員や避難器具製造業者などから使用方法の説 明を受けたときの理解と操作性の印象を表 13，表 14 に示す。生10)

理解の状況は，「十分わかった」「ある程度わかった」をあわせて，く 回転〉はく特養〉で $97.5 \%$ ，〈老健〉で $100.0 \%$ ，〈直線〉は〈特盖 〈老健〉ともに $100.0 \%$ で, 使用法は理解されている結果が得られ た。〈救助袋〉は，〈老健〉では理解にばらつきがある。操作性の 印象は，〈回転〉〈直線〉は「簡単」「比較的簡単了が多く，〈救助袋〉 は「やや難しい」「難しい」が「簡単」「比較的簡単」に比べ増加する。 また、「簡単」「比較的簡単」と「やや難しい」「難しい」とに分けた場 合，〈老健〉はく特養〉よりも「簡単」側に回答が多い。 表13 主な避難器具の説明に対する職員の理解 (施設数)

\begin{tabular}{|c|c|c|c|c|c|c|}
\hline & \multicolumn{2}{|c|}{ 〈回転〉 } & \multicolumn{2}{|c|}{ 〈西楾〉 } & \multicolumn{2}{|c|}{ 〈救助袋〉 } \\
\hline ヘ!十分わかった & 24 & $60.0 \%$ & 9 & $52.9 \%$ & 7 & $87.5 \%$ \\
\hline 特ある程度わかつた & 15 & $37.5 \%$ & 8 & $47.1 \%$ & 1 & $12.5 \%$ \\
\hline 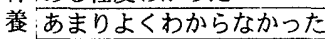 & 1 & $2.5 \%$ & 0 & $0.0 \%$ & 0 & $0.0 \%$ \\
\hline V ほとんどわからなかった & 0 & $0.0 \%$ & 0 & $0.0 \%$ & 0 & $0 . \overline{0 x}$ \\
\hline 合許 & 40 & $100.0 \%$ & $17 !$ & $100.0 \%$ & 8 & $100.0 \%$ \\
\hline ヘ!十分わかった & 35 & $76.1 \%$ & 8 & $72.7 \%$ & 6 & $35.3 \%$ \\
\hline 老ある程度わかった & 11 & $23.9 \%$ & 3 & $27.3 \%$ & 8 & $47.1 \%$ \\
\hline 健 あまりよくわからなかった & 0 & $0.0 \%$ & 0 & $0.0 \%$ & 3 & $17.6 \%$ \\
\hline Vほほとんどわからなかった & 0 & $0.0 \%$ & 0 & $0.0 \%$ & 0 & $0.0 \%$ \\
\hline 夻計 & 46 & 100.08 & 11 & $100.0 \%$ & 17 & $100.0 \%$ \\
\hline
\end{tabular}

表14 主な避難器具に対する職員の操作性の印象

(施設数)

\begin{tabular}{|c|c|c|c|c|c|c|}
\hline & \multicolumn{2}{|c|}{ 〈回転〉 } & \multicolumn{2}{|c|}{ 〈面線〉 } & \multicolumn{2}{|c|}{ 〈救助袋〉 } \\
\hline$\wedge$ 䇴単 & 19 & $47.5 \%$ & 8 & 44.48 & 2 & $25.0 \%$ \\
\hline 特 比較的简単 & 12 & $30.0 \%$ & 6 & $33.3 \%$ & 3 & $37.5 \%$ \\
\hline 養やや難しい & 4 & $10.0 \%$ & 3 & $16.7 x$ & 2 & $25.0 \%$ \\
\hline V難しい & 5 & 12.58 & 1 & $5.6 \%$ & 1 & 12.58 \\
\hline 合計 & 40 & $100.0 \%$ & 18 & $100.0 \%$ & 8 & $100.0 \%$ \\
\hline$\wedge$ 簡単 & 21 & 45.78 & 6 & $54.5 \%$ & T) & $5.9 \%$ \\
\hline 老比較的㙁箪 & 19 & $41.3 \%$ & 4 & $36.4 \%$ & 10 & $58.8 \%$ \\
\hline 健 やや難しい & 5 & $10.9 \%$ & 0 & $0.0 \%$ & 3 & $17.6 \%$ \\
\hline V難しい & 1 & $2.2 \%$ & 1) & $9.1 \%$ & 3 & $17.6 \%$ \\
\hline 鿖計 & 46 & $100.0 \%$ & 11 & 100.08 & 17 & $100.0 \%$ \\
\hline
\end{tabular}

\subsection{4. 入所者の使用に関する有効性}

実際の火災時を想定し，操作性（表 15)，設置場所（表 16)，心理 面 (表 17) に関して入所者が使用する場合の有効性を施設職員に判 断してもらった。⑪想定する入所者の移動能力は, 介助があれば 歩行可能から自力歩行可能な場合である。(なお，下記では，各表
表15 㩯作性(入所者が使用することの有効性について)

(施設数)

\begin{tabular}{|c|c|c|c|c|}
\hline & 〈回転〉 & & 直線〉 & 〈救助袋〉 \\
\hline 操作は可能で有効に使用できる & $10 ! 21.7 \%$ & 5 & $25.0 \%$ & $0: 0.0 \%$ \\
\hline 胿他の避難経路が無理ならば使用 & $37.0 \%$ & 12 & $60.0 \%$ & $0.0 \%$ \\
\hline 特器具使用でのみ助かるならば使用 & $18 \quad 39.1 \%$ & 3 & $15.0 \%$ & $75.0 \%$ \\
\hline どのような場合でも救助を待たせる & $2.2 \%$ & 0 & $0.0 \%$ & $25.0 \%$ \\
\hline その他 & $0.0 \%$ & 0 & $0.0 \%$ & $0.0 \%$ \\
\hline 合計 & \begin{tabular}{|l|l|}
46 & 100.08 \\
\end{tabular} & 20 & $100.0 \%$ & $8,100.0 \%$ \\
\hline 操作は可能で有効に使用できる & \begin{tabular}{l|l|}
9 & $18.8 \%$ \\
\end{tabular} & 21 & $18.2 \%$ & $0 ! \quad 0.0 \%$ \\
\hline 他の避難経路が無理ならば使用 & $58.3 \%$ & 7 & 63.68 & 29.48 \\
\hline 艺器具使用でのみ助かるならば使用 & $11^{1} 22.9 \%$ & 2 & $18.2 \%$ & $52.9 \%$ \\
\hline どのような場合でも救助を待たせる & $0.0 \%$ & 0 & $0.0 \%$ & 11.88 \\
\hline その他 & $0: 0.0 \%$ & 0 & $0.0 \%$ & $1 \quad 5.9 \%$ \\
\hline 合計 & \begin{tabular}{|l|l|}
48 & $100.0 \%$ \\
\end{tabular} & III & 100.08 & \begin{tabular}{l|l|l|l|}
17 & $100.0 \%$ \\
\end{tabular} \\
\hline
\end{tabular}

表16 設置場所(入所者が使用することの有効性について)

(施設数)

\begin{tabular}{|c|c|c|c|c|}
\hline & 〈回転〉 & & 直線> & 〈敖助袋〉 \\
\hline 設置場所は適切で有効に使用できる & $12,26.7 \%$ & 3 & $15.0 \%$ & $0 \quad 0.0 \%$ \\
\hline 他の避難経路が無理ならば使用 & $37.8 \%$ & 14 & $70.0 \%$ & \\
\hline 特具使用でのみ助かるならば使用 & $35.6 \%$ & 3 & $15.0 \%$ & $85.7 \%$ \\
\hline どのような場合でも救助を待たせる & $0.0 \%$ & 0 & $0.0 \%$ & $14.3 \%$ \\
\hline 文の他 & $0.0 \%$ & 0 & $0.0 \%$ & $0: 0.0 \%$ \\
\hline 合計 & $45: 100.0 \%$ & 20 & $100.0 \%$ & $7: 100.0 x$ \\
\hline !設置場所は適切で有効に使用できる & $10 ! 20.4 \%$ & 2 & $18.2 \%$ & $2: 11.8 \%$ \\
\hline 他の避難経路が無理ならば使用 & 57.18 & 7 & $63.6 \%$ & $35.3 \%$ \\
\hline のみ助かるならば使用 & $22.4 \%$ & 2 & $18.2 \%$ & $41.2 \%$ \\
\hline 健 炎のような場合でも救助を待たせる & $0.0 \%$ & 0 & 0.0 & $5.9 \%$ \\
\hline その他 & $0.0 \%$ & 0 & 0.08 & 5.98 \\
\hline & $100.0 \%$ & & $00.0 \%$ & \\
\hline
\end{tabular}

表17 心理面(入所者が使用することの有効性について)

\begin{tabular}{|c|c|c|c|c|}
\hline & $\langle$ 回転〉 & & 直線〉 & 〈救助袋〉 \\
\hline ヘ心理的抵抗は少なく有効に使用できる & $7 ! \quad 15.2 \%$ & & $10.0 \%$ & $0 ! \quad 0.0 \%$ \\
\hline 特他の避難経路が無理ならば使用 & $16: 34.8 \%$ & 131 & 65.08 & $0.0 \%$ \\
\hline 特 器具使用でのみ助かるならば使用 & $20,43.5 \%$ & 5 & $25.0 \%$ & $75.0 \%$ \\
\hline どのような場合でも救助を待たせる & $6.5 \%$ & 0 & $0.0 \%$ & $25.0 \%$ \\
\hline$\checkmark$ その他 & $0.0 \%$ & 0 & $0.0 \%$ & $0.0 \%$ \\
\hline 含許 & \begin{tabular}{l|l|}
46 & $100.0 \%$ \\
\end{tabular} & 20 & $100.0 \%$ & $8: 100.0 \%$ \\
\hline 心理的抵抗は少なく有効に使用できる & $8 \quad 16.38$ & 2 & 18.28 & $0.0 \%$ \\
\hline 他の避難経路が無理ならば使用 & $57.1 \%$ & 6 & $54.5 \%$ & $23.5 \%$ \\
\hline 器具使用でのみ助かるならば使用 & $26.5 \%$ & 3 & $27.3 \%$ & $64.7 \%$ \\
\hline どのような場合でも救助を待たせる & $0.0 \chi$ & 0 & $0.0 \%$ & $5.9 \%$ \\
\hline その他 & $0.0 \%$ & 0 & $0.0 \%$ & $5.9 \%$ \\
\hline 合計 & $\begin{array}{l:l}49 & 100.0 \% \\
\end{array}$ & 11 & $100.0 \%$ & $17: 100.0 \%$ \\
\hline
\end{tabular}

の上側 $2 つ$ 選択肢を合わせて「使用させる側」，その次の 2 つの選 択肢を合わせて「使用させない側」と表現する。）

・〈回転〉操作性は，「操作は可能で有効に使用できる」「他の避難 経路が無理ならば使用」を合わせた「使用させる側」の回答割合は,く 特養〉より〈老健〉が多い。設置場所も操作性と同様の傾向がある が，心理面はく特養〉〈老健〉ともに「心理的抵抗は少なく有効に使 用できる」が減少し、「他の避難経路が無理ならば使用」「器具使用で のみ助かるならば使用」が增える。

•〈直線〉〈特養〉〈老健〉ともに, 操作性, 設置場所, 心理面い ずれも「他の避難経路が無理ならば使用」がもつとも多い。「使用させ る側」の回答割合は, 操作性, 設置場所はく回転〉よりも多いが, 心 理面ではほとんど差がない。

〈〈救助袋〉〈特着〉〈老健〉ともに操作性, 設置場所, 心理面い ずれも「器具使用でのみ助かるならば使用」がもっとも多い。また， 〈回転〉〈直線〉に比べて,「器具使用でのみ助かるならば使用」どの ような場合でも救助を待たせる」を合わせた使用させない側」の回 答割合が増え，とくにく特養〉でその傾向が強い。

\section{3. 5. 考察}

三種類の避難器具のうちく直線〉〈救助袋〉で,〈特盖〉と〈老健 $>$ の設置割合が逆の結果となった。これは,〈特盖〉より高層の多 いく老健〉で低層向けのく直線〉の設置が少なく, 逆に高層でも使 用できるく救助袋〉が多いためといえる。施設職員による避難器具 の使用方法はほぼ理解されているが，操作性の印象は，とくにく救 助袋〉でばらつきが大きかった。これはく回転〉直線〉は避難器具 


\section{4.5. 夜間を想定した防災訓練の実施状況}

夜間想定の防災訓練の実施状況を表 22 に示す。実施時間帯の昼 間と夜間はとくに時間を指定せず回答を得ている。く特盖〉の 98.8 \%，〈老键〉の $97.8 \%$ で夜間を想定した訓練を実施している。昼 間，夜間ともく特盖〉のほうが入所者も参加する場合が多く，とく に夜間は〈特盖〉は $20.7 \%$ でく老健〉の $5.6 \%$ よりかなり多い。せ14) 表22 夜間想定の防災訓練実施状況

\begin{tabular}{|c|c|c|c|c|c|c|c|c|c|}
\hline & & & & & & & & & \\
\hline 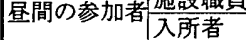 & 0 & 0 & 0 & $\frac{x}{x}$ & $\frac{x}{x}$ & $\frac{x}{x}$ & $\frac{a}{x}$ & $\frac{\hat{x}}{x}$ & $\frac{x}{x}$ \\
\hline 者施設職買 & 0 & 0 & $x$ & $x$ & 0 & 0 & 0 & 0 & $x$ \\
\hline 啫入所者 & 0 & $x$ & $x$ & $x$ & 0 & $\bar{x}$ & 0 & $\frac{x}{x}$ & $x$ \\
\hline 〈特美〉N=257 & 22 & 11 & 149 & 32 & & & 29 & & \\
\hline 〈将趛〉 $N=206$ & $8.6 \%$ & $4.3 \%$ & $58.0 \%$ & $12.5 \%$ & $0.8 \%$ & $0.8 \%$ & $11.3 \%$ & 2.78 & $1.2 x$ \\
\hline 〈老健〉N=179 & \begin{tabular}{|r|}
5 \\
28
\end{tabular} & $\begin{array}{r}3 \\
17 \%\end{array}$ & 115 & 38 & 0 & 1 & 5 & 8 & \\
\hline
\end{tabular}

\subsection{6. 考察}

入所者の参加項目のなかでは，垂直移動に関する項目の参加率は 水平移動より低い。入所者の身体能力が低いのは事実であるが，火 災時は, 地上への避難がもっとも安全であるので, 現状, 防災訓練 の実施状況は，やや不十分といえる。あるいは，防火区画のより有 効な計画を行うことにより, 入所者は水平移動のみで安全な場所に 避難できる配慮も必要である。

防災訓練時に入所者が避難器具を使用する割合は，〈特盖〉ょり 表 23 分類条件

\begin{tabular}{|c|c|c|c|}
\hline & 分類条件 & 略称 \\
\hline \multirow{8}{*}{$\begin{array}{l}\text { 分 } \\
\text { 類 } \\
\text { 項 } \\
\text { 目 }\end{array}$} & \multirow{2}{*}{ 入所階 } & 玄関階に入所している & 「玄関階」 \\
\hline & & 玄関階以外に入所している & 「玄関階以外」 \\
\hline & \multirow{2}{*}{$\begin{array}{l}\text { 恋と空の防煙区画 } \\
\text { (扉·空の組合せ })\end{array}$} & $\begin{array}{l}\text { 「覀あり」壁もしくはガラス空等あり」 } \\
\text { の居窒 (表 } 6 \text { ) }\end{array}$ & 「完全」 \\
\hline & & 上記以外の組み合わせの居室(表6) & 「不完全」 \\
\hline & \multirow{2}{*}{ 居室と } & 直接バルコニーに出られる居室 & 「出られる! \\
\hline & & 直接バルコニーに出られない居室 & 「出られない」 \\
\hline & \multirow{2}{*}{ 移動能力 } & 「自力移動困難者了以外 & 「自力移動者」 \\
\hline & & 「自力移動困難者」 & 「自力移動困難者」 \\
\hline
\end{tabular}

表 24 居室状況別の居住者数の分類〈特養〉 合計10070人（175施設）

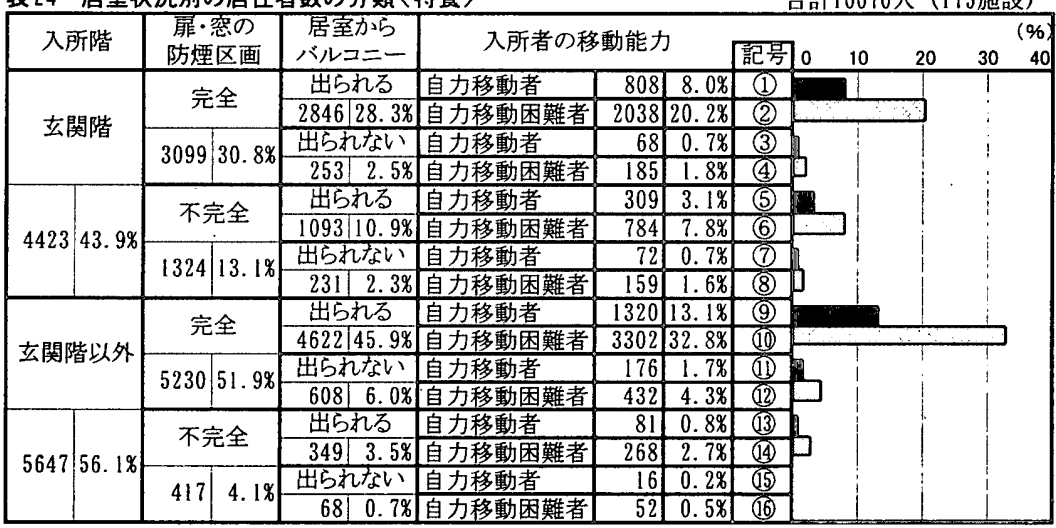

表 25 居室状況別の居住者数の分類〈老健〉 合計10984人（136施設）

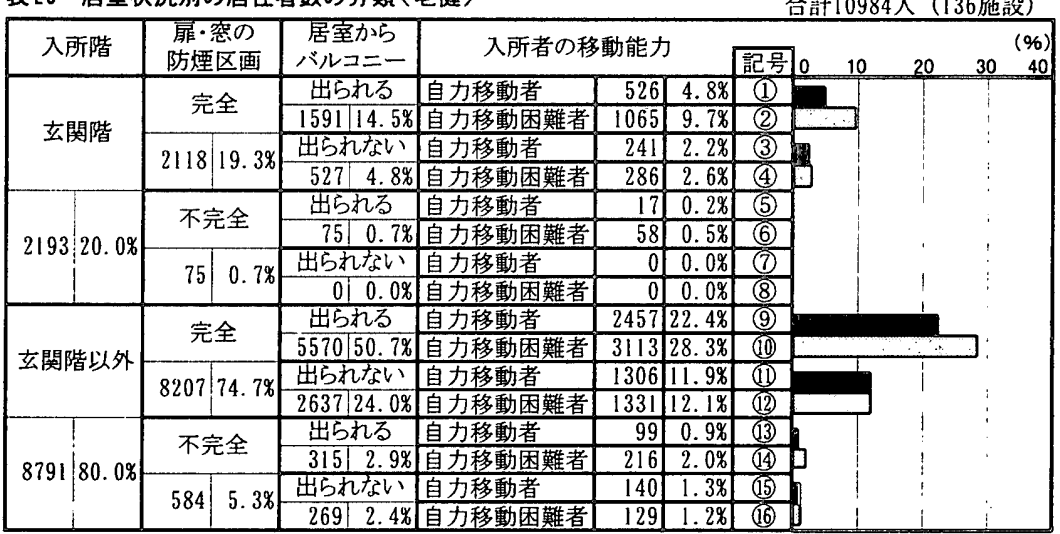

〈老健〉のほうが多い結果が得られたが，これはく特盖〉よりもく 老健〉のほうが身体能力の高い入所者が多いことが理由といえ, 施 設職員が入所者の使用に積極的でないく救助袋〉で使用割合が高い ことがそれを裏づけている。

防多訓練の実施回数は，〈特養〉は〈老健〉よりも多い。〈老健〉 は一時入所であるが, 〈特盖〉は居住が目的のため, 〈特盖〉は計 画的に防災訓練を実施しやすいことが理由の一つと考えられる。

防災訓練への参加と身体状況については, 介護の必要性が高いと いう理由だけで参加を制限しているわけではないことが分かった。 これは，身体状況に応じて各個人が参加できる範囲で参加している と推測でき, 身体状況に応じた防災訓練の実施項目を設定し, 反復 訓練を行うことにより，実施項目は少ないながらも確実に行動でき るようにする訓練方法も可能であることを示唆している。

\section{5. 居室条件別の入所者人数}

表 23 の条件を組合せて居室条件を分類し, 各入所者数を集計し た結果が表 24 , 表 25 である。本分析は, 表 23 の全項目に有効な回 答が得られたく特盖〉175, 〈老健〉136, 計 311 施設で行っている。 なお下記文章中の(1)〜161は，表 24，表 25 における(1)〜16)を示す。 ・〈特盖〉最も有利な建築条件の入所者（1(2)）は $28.3 \%$, 最も 不利な建築条件の入所者（15(16)）は $0.7 \%$ で最も少ない。居室への 煙の流入を防ぐことのできる, 屝・公の防煙区画が「完全」(1)〜(4), (9)〜(12) は $82.7 \%$ であるが, (2)〜 (4), (10〜(12)の $61.5 \%$ は，人的介 助を必要とする。仮に, バルコニーに出られる構造とすれば, (1)(3) (9)(11) $23.5 \%$ が自力で避難できる。屝・㥶の防煙区画が「不完全」 の場合は， $17.2 \%$ であるが，仮に屝・窓の防煙区画が整備された場 合，とくに「不完全」「自力移動困難者」の組み合わせ（6)(8)(14)(16) $12.6 \%$ 安全性が高まる。自力でバルコニ一から避難できる「出ら れる」「自力移動者」の組み合わせ（11(5)(9)(13)）は $25.0 \%$ で, 残りの $75.0 \%$ ，バルコニーが設置さ れていないか介助が必要の理由で, バルコニーか らの避難ができない。ここで, 仮にバルコニーが 整備されて居室から出られるようになると,「出ら れない」「自力移動者」のうち $3.3 \%$ (3)(7)(11(15) が, バルコニーからの避難が可能になる。

・〈老健〉最も有利な建築条件の入所者 (1)(2) は $14.5 \%$, 最も不利な建築条件の入所者（15)(16) は $2.4 \%$ く特盖〉より多い。罪・空の防煙区画が「完 全」(1)〜(4), (9)〜(12)）は94.0\%であるが, (2)〜 (4), (10)〜12)の $66.8 \%$ は，人的介助を必要とする。仮に， バルコニーに出られる構造とすれば, (1)(3)(911) $41.3 \%$ 自力で避難できる。屝・宓の防煙区画が 「不完全」の場合は，6.0\%であるが，仮に扉・空の 防煙区画が整備された場合，とくに「不完全」自力 移動困難者」の組み合わせ（6)(8)(14)(16)３.7\%の安 全性が高まる。自力でバルコニーから避難できる 「出られる」「自力移動者」の組み合わせ（(1)(5)(9)(13) は $28.3 \%$, 残りの $71.7 \%$ は, バルコニーが設置 されていないか介助が必要の理由で, バルコニー からの避難ができない。ここで, 仮にバルコニー が整備されて居室から出られるようになると,「出 
られない」自力移動者」のうち $15.4 \%$ (3)(7)(11(15) が，バルコニー からの避難が可能になる。

\subsection{1. 考察}

火災時の避難安全の視点では，玄関階以外の入所は不利であり， さらにバルコニーへ出られないことが多いく老健〉の現状は改善の 必要がある。「最も不利な条件」も〈老健〉は〈特養〉より多い。建築 条件である罪・空の防煙区画の整備はとくに「自力移動困難者」の安 全に寄与する。さらに，バルコニーが整備されれば,「自力移動者」 はバルコニーを経由する避難経路を有効に活用できるようになり， 「自力移動困難者」も介助があればバルコニーから避難でき，避難安 全性は大きく向上する。さらに地上に避難するために高齢者が有効 に使用できるような避難器具の整備が重要になる。

\section{4. まとめ}

火災時には,「人的条件」「建築条件」各種器具 (避難器具等) 条件」 「防災訓練での経験」が相互に有効に補い，安全な避難が可能とな る。本稿では, 入所者の移動能力に着目し、「人的条件」を考察した。 廊下を経由する避難を想定した「建築条件」では，入所者に対する日 常介護と避難安全が両立されていない現状を示した。「防災訓練」で は，居室と同一階のデイルーム等を防火上重要な位置づけとできる 可能性が得られた。バルコニーを経由する「避難器具」では, 防災訓 練時の使用傾向や，入所者の使用に関して施設職員の意識が避難器 具ごとにばらつきが生じた。これは法的な基準を満たしただけでは 有効な避難器具とはなり得ないことを示している。「居室条件別の居 住者人数」の考察では，居室の防火安全性と入所者の移動能力の関 係は反映されていない現状が示され，より実践的な建築計画・避難 器具の開発や改良等は早急に望まれる。

注 1) 文献1によると、特別盖護老人ホームからの「入所者が避難器具を使 用できないのではないか」との意見に着目していて、今後の検討項目 の一つとして避難器具を提起している。また、文献 4 によると、各種 老人ホームの火災事例をもとに、避難器具の有效性についての师究の 必要性を提起している。また、文献 9 では、避難場所としてバルコニー の有効性を指摘しているが、同時に、バルコニー自体の問題により避 難できないなどの事例も挙げ、設計時点からの有効な避難計画を検討 することの必要性を指摘している。

注 2）65 歳以上で、身体上または精神上著しい障害のため常時の介謨が必姴 で、居宅においての生活が困難な者が入所対象となる。入所者に対し て、入浴、排泄、食事等の介護、日常生活上の世話を行う。

注 3）病状安定期にあり、入院治療する必要はないが、リハビリテーション、 看護、介䜅を中心とした医療ケアを必要とする者が入所対象となる。病 院と居宅の中間に位置する施設で、家庭復帰を目的としている。

注 4）複数の建物 (楝)に居室のある施設は、運営上建物ことに入所者の身体 状況等を分けている場合があり、別々の建物として分析すると、入所 者の移動能力の分布に偏りを生じさせる可能性があるため、除外した。

注 5)〈老健〉に1979 年建設があるが、これは用途変更によるものである。

注6）注 8）建物から避難する場合、日常使用する玄関から屋外へ出ること が、混乱を生じない最も望ましい経路といえる。本稿ではこの点を重 視し、建物自体の階数でなく、玄関を基準とした階数の差を使用した。

注7）「屝なし」は「カーテン」「アコーディオンドア」「戸などは無し」を含む。こ こでいう「ほな゙゙は無し」は、建設時点で無かったか途中で撤去された かは区別していない。「愿下側空の状態」「すき間あり」は、ガラスのは め込まれていないふすすま」障子等が設置されている状態である。

注 9）避難器具の設置は消防法施行令第 25 条に規定されていて、本稿で対参 としている〈特美〉老健〉.は、対象防火建築物の「福祉施設」に該当す る。避難器具を必要とするのは基本的に 2 階以上の階または地階で、そ
の階の収容人数が 20 人以上の場合である。適応避難器具を次表に示す。

\begin{tabular}{|c|c|c|c|c|c|c|}
\hline 名称 & 地階 & 2 階 & 3階 & 4 階 & 5 階 & 6階以上 \\
\hline 〈すべり台〉 & & 0 & 0 & $\odot$ & 0 & 0 \\
\hline 〈救助袋〉 & & 0 & 0 & 0 & 0 & 0 \\
\hline 〈はしご〉 & 0 & 0 & & & & \\
\hline 〈夕ラップ & 0 & 0 & & & & \\
\hline 〈悢降機〉 & & 0 & 0 & 0 & 0 & \\
\hline 〈避難橋〉 & & 0 & 0 & 0 & 0 & 0 \\
\hline
\end{tabular}

注 10）注 11）注 13）回答者の負担を考虑し、ここでは、「回転〉」と「回 転〉以外でもっともよく説明等を受けている器具一つ」について回答を 依頼している。〈回転〉を独立させて質問しているのは、設置数が多い ことが予想されたためである。

注 12)「自力移動困難者」の割合を検定変数、実施の有無をグループ化变数と して Mann-Whi Iney の・U检定を行った。結果は、〈特姜〉の「避難器具 使用の勉強会」以外の漸近有意確譬（両側）は５\%萧却水潐より高い 結果が得られ、〈特盖〉老健〉とも、「自力移動困難者」の占める割合 で参加の有無に差異があるのではないことが示された。

注 14）「自力移動困難者」の割合を検定变数、入所者参加の有無をクループ化 变数としてMann-Thi IneyのU検定を行った。結果は、濑近有意確率 (画側) が、入所者が昼間参加する場合、夜間参加する場合でいずれも $5 \%$ 寨却水準より高い值を示していて、入所者参加の有無は、「自力移 動困難者」の占める割合とは関係ないことが示された。

参考文献

1）東京消防仃火災予防審議会：災害弱者施設に関する防火アンケート調査結 果報皆韭, 1992.3

2) 室崎益阽：高㱓化社会における建策物の安全の考元方, 日本火災学会誌 Vol. 42 No. 4 , pp. $1-3,1992.8$

3）野村歡, 志田弘二: 就复機能をもつ社会福祉施設・病院の夜間防火対策, 日本火災学会誌, Vol. 42 No. 4, pp.4-11,1992.8

4) 林玉子：高龄者の行動特性と安全対策のあり方, 日本火炎学会誌, Vol. 42 No. 4, pp. 12-20,1992.8

5) 古濑敏 : 高齢者・障害者の火災時の安全をどうかんがえるべきか一近年の 外国の動きを見る一，日本火災学会誌，Vol. 42 No. 4, pp. 25-29, 1992.8

6）矢代敋郎：災害弱者施設における防火対策「水平避難」，日本火災学会誌 , Vol. 42 No. 5, pp. 24-30,1992.10

7) 吉村英祐, 田中直人，柏原士郎，横田隆司，阪田弘一：下肢障害者の移動 能力と火災時の避難に対する意識の関係 身体障害者の避難安全計画に関 する研究 その 1 , 日本建築学会計画系論文集，第 541 号, p p. 101 $108,2001.3$

8）矢代壵郎，広田正之，掛川秀史：防火規定の変罯にもとづく防火性能上の 建築物の年代区分（工学的火災安全性評佂法に上る建築物の火災りスク評 価に関する研究），日本建筑学会技術報告集，第 5 号，p p . 132 137, 1997.12

9）社会福祉・医䍃事業団：社会福祉施設経営セミナー 資料 II 設計・建筑 ，社会福祉・医療事業団，2000.6

消防庁予防課：社会福祉施設・病院 夜間の防火管理体制指導マニュアル の解説，財団法人日本防火研究普及協会, 1989.9

10）消防庁予防課：災害弱者利用施設等防火安全対策検討報告聙（平成 6 年度） , 1995.3

11) 海老原学, 掛川秀史 : 介助行動を考慮できる避難シミュレーション，日本 火災学会誌, Vol.43 №.3,ppl1-18, 1993.6

12) 志田弘二 : 火災データベースを利用した病院・福祉施設の火災リスク分析 日本建築学会学術講演梗概集，1998.A2,pp95-96, 1998.9

13）中血儌, 桜井学, 川村かお里, 值井英雄 : 防災㖕画晢に見る最近の避難計 画の実熊に関する調查研究 その1。病院・老人保健施設の基準階を対象 として，日本建築学会学術䜺演梗概集，2000.E1, pp.975-976,2000.9

14）眅田稳, 村井健祐：避難行動に関する研究 一年代原別にみた避難行動特 性とその対策一，日本火炎学会論文集，第 42 巻 2 号, pp. 17-28, 1995.2

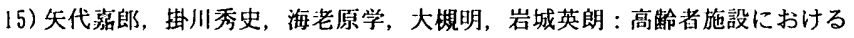
水平避難方式の効果 災害弱者施設の火災安全対策（その4），日本建築 学会学術請演梗概集, 1993.A, pp.1341-1342,1993.9

(2001年6月 8 日原稿受理, 2001 年 9 月 6 日採用決定) 